\title{
CHARACTERIZATION OF DEGRADATION PRODUCTS OF POLYETHYLENE OXIDE BY PYROLYSIS MASS SPECTROMETRY
}

\author{
M. M. FARES, ${ }^{1}$ J. HaCAlOGLU ${ }^{1 *}$ and S. Suzer ${ }^{2}$ \\ 'Faculty of Arts and Science, Chemistry Department, Middle East Technical University, \\ 06531 Ankara, Turkey \\ ${ }^{2}$ Chemistry Department, Bilkent University, 06533 Ankara, Turkey
}

(Received 26 May 1993; accepted 8 September 1993)

\begin{abstract}
The techniques of direct and indirect (evolved gas analysis) pyrolysis MS are used to characterize the thermal degradation products of polyethylene oxide. Using direct pyrolysis MS technique the main degradation process is determined to be due to $\mathrm{C}-\mathrm{O}$ and $\mathrm{C}-\mathrm{C}$ scissions yielding fragments characteristic of the polymer. Evolved gas analysis indicates formation of small molecular stable compounds such as $\mathrm{C}_{2} \mathrm{H}_{5} \mathrm{OC}_{2} \mathrm{H}_{5}, \mathrm{CH}_{3} \mathrm{CHO}, \mathrm{CO}_{2}, \mathrm{CO}$ and $\mathrm{C}_{2} \mathrm{H}_{4}$.
\end{abstract}

\section{INTRODUCTION}

Polyethylene oxide, PEO, is a tough ductile highly crystalline thermoplastic and is readily soluble in water. It is finding increasing commercial use $[1,2]$ in the form of disposable laundary bags, packaging for agricultural seeding, hazardous dyes and detergents, chromatographic stationary phases and wet-track adhesives. It is also used as a conducting medium in light weight energy density batteries [3]. Although, chemical and physical characteristics of PEO have been extensively studied, only few reports about thermal $[1,4,5]$ or thermo-oxidative $[6,7]$ stability and degradation appeared in the literature.

Thermal degradation of polymers have been studied with different techniques; differential scanning calorimetry $[5,6]$, thermo gravimetric method [1, 4], thermal volatilization analysis [8], dynamic mechanical thermal analysis [2], pyrolysis, evolved gas analysis [9-13] by i.r., MS or GC. However most of the commonly used thermal analysis methods can not give any information about the chemical nature of the degradation products. Recently pyrolysis products of several polymers by i.r. and MS have been studied in our laboratory [9-11]. Now, we report results obtained by a more direct pyrolysis technique applied to analyze thermal degradation products of PEO.

\section{EXPERIMENTAL PROCEDURES}

Standard PEO homopolymer with $M_{w}$ of $9 \times 10^{5}$ and $4 \times 10^{6} \mathrm{~g} \cdot \mathrm{mol}^{-1}$ were obtained from Aldrich chemical company. In direct pyrolysis experiments, $20 \mu 11 \%(\mathrm{w} / \mathrm{v})$ PEO-ethyl alcohol solution was placed inside the sample holder and the solvent was evaporated to dryness at room temperature. In direct pyrolysis (evolved gas analysis) experiments $10 \mathrm{mg}$ samples were used.

For direct pyrolysis experiments, a probe (Fig. 1) that can be inserted directly inside the mass spectrometer through a

*To whom all correspondence should be addressed. valve that allows differential pumping of the probe inlet line was designed. It is basically composed of a stainless steel tube connected to a copper assemble carrying the copper sample holder. A heater is placed inside the stainless steel tube, and a thermocouple is connected to measure temperature.

The system used for evolved gas analysis was similar to the one described in our previous studies $[9,10]$. Simply it consists of an oven, a pyrex reactor chamber and a needle valve which is connected to the mass spectrometer.

Duplicate runs indicated high reproducibility of the techniques used. The mass spectrometer was Balzers QMG 311 quadrupole mass spectrometer conected to a personal computer for the control of the MS, data acquisition and analysis.

\section{RESULTS AND DISCUSSION}

\section{Direct pyrolysis analysis}

Thermal degradation products of PEO $\left(M_{\mathrm{w}}=\right.$ $9 \times 10^{5} \mathrm{~g} \cdot \mathrm{mol}^{-1}$ ) were studied by recording mass spectra as a function of temperature. The temperature was increased to $120^{\circ}$ rapidly and then the sample was heated at a rate of $15^{\circ} / \mathrm{min}$ until the temperature reached $210^{\circ}$. Finally the rate of heating was decreased to $1 \%$ min and kept constant.

The peak of 45 a.m.u. was the first that appeared at $140^{\circ}$ and increased slowly until it reached a maximum of $222^{\circ}$. Then it nearly disappeared around $230^{\circ}$. At $235^{\circ}$ it again showed up together with the peaks related to dimer $(m / z=89$ a.m.u. $)$ trimer ( $m / z=133$ a.m.u. $)$ tetramer $(m / z=177$ a.m.u. $)$, pentamer $(m / z=221$ a.m.u.) and hexamer $(\mathrm{m} / \mathrm{z}=$ 265 a.m.u.). Ion yields increased rapidly and reached their maximum values at $248^{\circ}$ and disappeared totally at $254^{\circ}$. Thus, it can be concluded that the degradation of the polymer mainly occurred at $235-255^{\circ}$ range. The main peaks observed in the mass spectra represent $\mathrm{CH}_{3} \mathrm{CH}_{2} \mathrm{O}\left(\mathrm{CH}_{2} \mathrm{CH}_{2} \mathrm{O}\right)_{\mu}^{+}$, $\mathrm{CH}_{3} \mathrm{CH}_{2} \mathrm{O}\left(\mathrm{CH}_{2} \mathrm{CH}_{2} \mathrm{O}\right)_{n} \mathrm{CH}_{2}^{+}$and $\mathrm{CH}_{3} \mathrm{CH}_{2} \mathrm{O}$ $\left(\mathrm{CH}_{2} \mathrm{CH}_{2} \mathrm{O}\right)_{n} \mathrm{CH}_{2} \mathrm{CH}_{2}^{+}$fragments where $n=0-6$. Relatively weaker peaks due to hydrogen losses from 


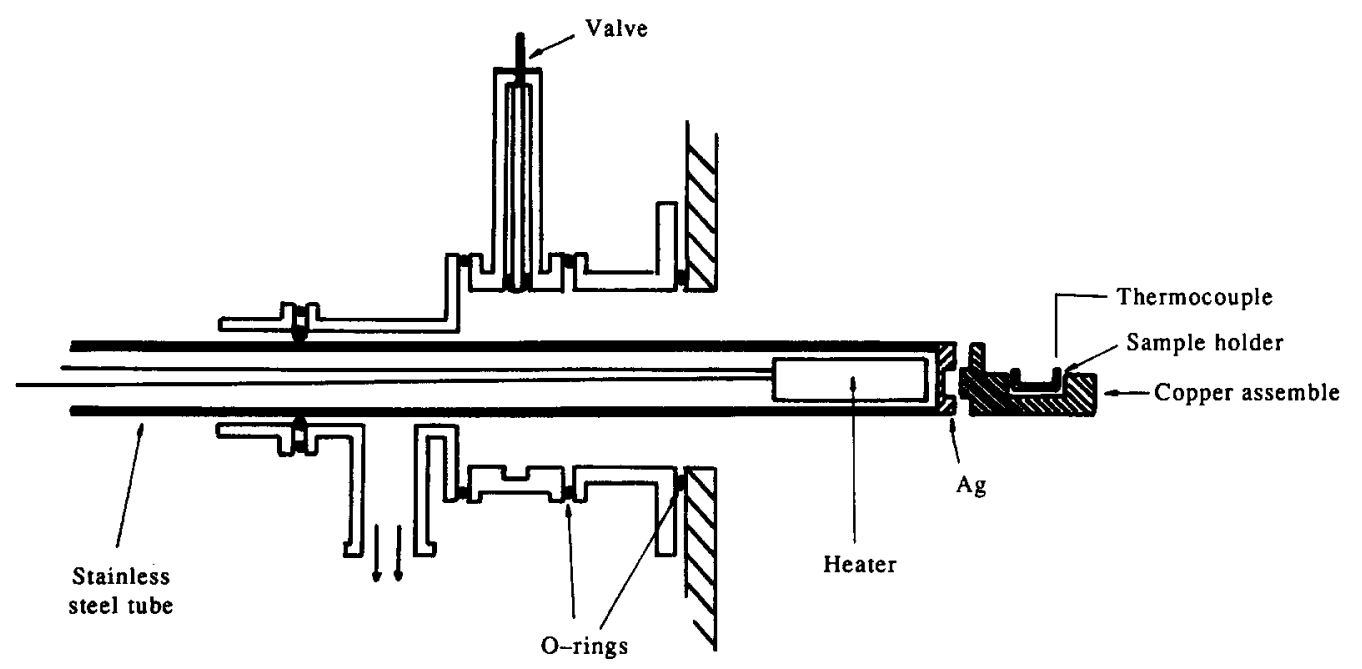

Fig. 1. Pyrolysis probe.

these main fragments were also present. The base peak was the monomer peak at 45 a.m.u., $\mathrm{CH}_{3} \mathrm{CH}_{2} \mathrm{O}^{+}$, throughout the experiment at any temperature. Relative intensities of the main peaks decreased as the chainlength increased. Variation of intensities of peaks related to monomer, dimer, trimer and tetramer as a function of temperature are given in Fig. 2. In general stability of a radical fragment decreases with chain length. The experimental observations are in accordance with this fact. However, one should also consider the fragmentation of the degradation products in the ion source of the mass spectrometer. Ionization of the thermal decomposition products with energetic electrons will cause further fragmentation which in turn results in considerable increase in the relative abundances of the low mass ions.

$$
\begin{aligned}
& \mathrm{MCH}_{3} \mathrm{CH}_{2} \mathrm{O}\left(\mathrm{CH}_{2} \mathrm{CH}_{2} \mathrm{O}\right)_{n} \mathrm{CH}_{2} \mathrm{CH}_{2} \mathrm{Om} \\
& \stackrel{\Delta}{\rightarrow} \mathrm{CH}_{3} \mathrm{CH}_{2} \mathrm{O}\left(\mathrm{CH}_{2} \mathrm{CH}_{2} \mathrm{O}\right)_{n}^{\cdot} \\
& \mathrm{CH}_{3} \mathrm{CH}_{2} \mathrm{O}\left(\mathrm{CH}_{2} \mathrm{CH}_{2} \mathrm{O}\right)_{n}^{\cdot}+\mathrm{e}^{-} \\
& \text {where } n>m \\
& \rightarrow \mathrm{CH}_{3} \mathrm{CH}_{2} \mathrm{O}\left(\mathrm{CH}_{2} \mathrm{CH}_{2} \mathrm{O}\right)_{m}^{+}
\end{aligned}
$$

In order to investigate the extent of fragmentation in the mass spectrometer, analysis of pyrolysis products of the same sample were carried out at different electron energies; $65,50,40,30$ and $20 \mathrm{eV}$. In all these experiments degradation occurred at the same temperature range $\left(235-255^{\circ}\right)$ revealing the high reproducibility of the pyrolysis technique used. In Fig. 3, mass spectra recorded at $248^{\circ}$, corresponding to maximum product yield temperature, using $65,50,40$, 30 and $20 \mathrm{eV}$ electrons are plotted. It can be observed from the figure that relative intensities of the higher mass peaks increased noticeably as the electron energy decreased. The base peak shifted to mass 89 a.m.u. (dimer) and relative intensities of higher mass fragments increased compared to the monomer peak. A three fold increase in case of dimer and tetramer and about a four fold increase in case of trimer and pentamer were observed (Table 1). Identical increases in relative intensities of the peaks related to $\mathrm{CH}_{3} \mathrm{CH}_{2} \mathrm{O}\left(\mathrm{CH}_{2} \mathrm{CH}_{2} \mathrm{O}\right)_{n} \mathrm{CH}_{2}^{+}$and $\mathrm{CH}_{3} \mathrm{CH}_{2} \mathrm{O}$ $\left(\mathrm{CH}_{2} \mathrm{CH}_{2} \mathrm{O}\right)_{n} \mathrm{CH}_{2} \mathrm{CH}_{2}^{+}$ions were also detected.

The variation of intensities of peaks related to monomer, dimer, trimer and tetramer as a function of temperature recorded at $20 \mathrm{eV}$ are shown in Fig. 4 . A very similar trend in degradation of the polymer as a function of temperature can be observed from the figure. But notice also the differences in the relative intensities. Although the relative intensity of the peak at 45 a.m.u. decreased above $230^{\circ}$, it considerably

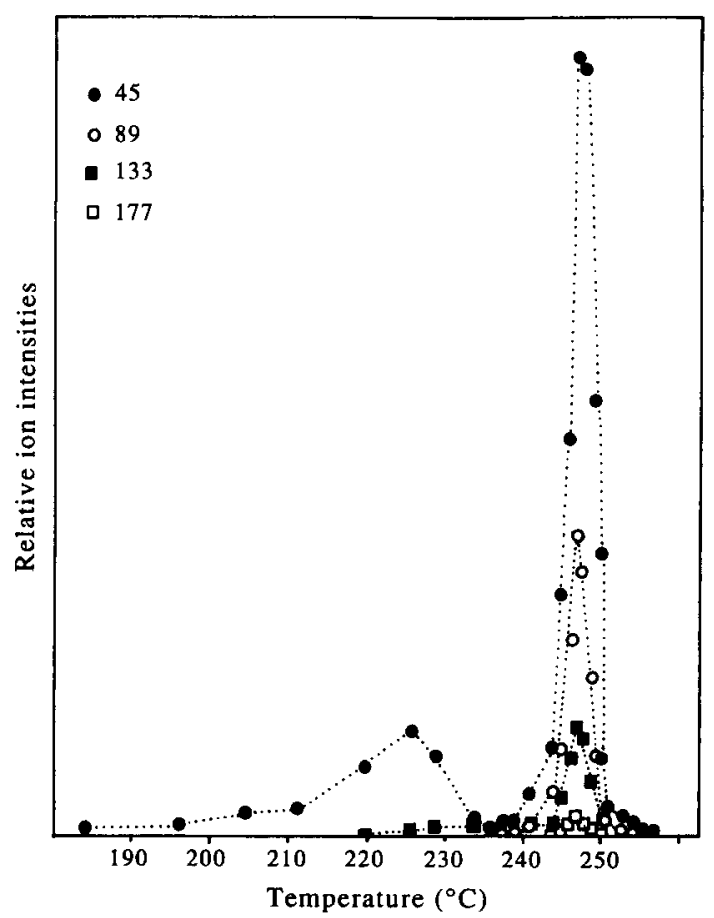

Fig. 2. Variation of intensities of peaks at 45, 89, 133, 177 a.m.u. as a function of temperature at ionization energy of $65 \mathrm{eV}$. 


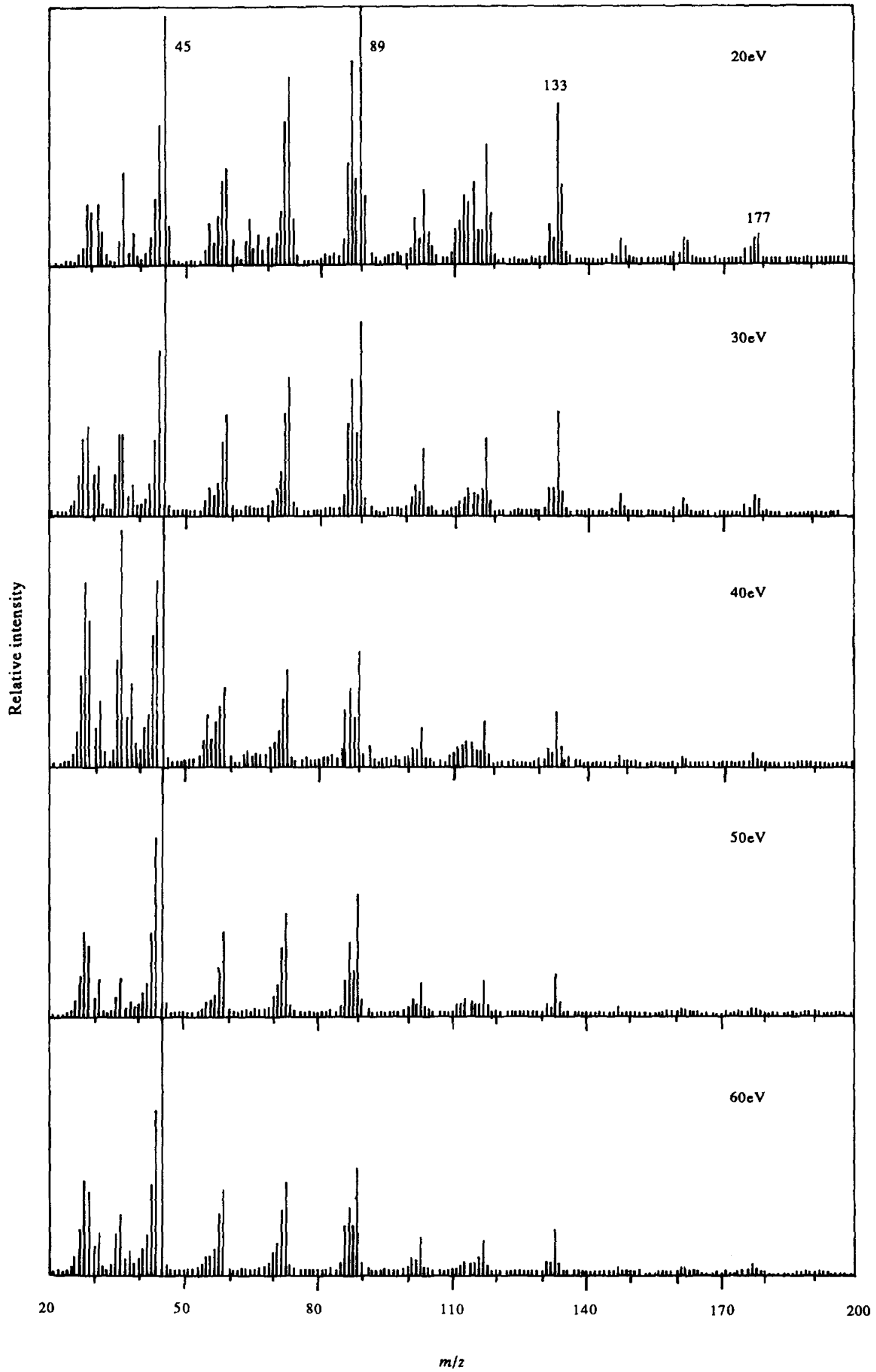

Fig. 3. Mass spectra of pyrolysis products of PEO at $248^{\circ}$ at various electron energies. 


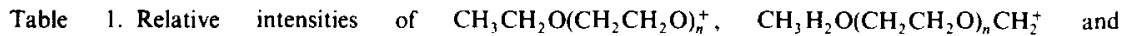
$\mathrm{CH}_{3} \mathrm{CH}_{2} \mathrm{O}\left(\mathrm{CH}_{2} \mathrm{CH}_{2} \mathrm{O}\right)_{n} \mathrm{CH}_{2} \mathrm{CH}_{2}^{+}$ions at various electron energies at 248

\begin{tabular}{|c|c|c|c|c|c|c|}
\hline \multirow[b]{2}{*}{$\begin{array}{c}\text { Peak } \\
\text { (a.m.u.) }\end{array}$} & \multicolumn{5}{|c|}{ Relative intensity } & \multirow[b]{2}{*}{ Assignment } \\
\hline & $65 \mathrm{eV}$ & $50 \mathrm{eV}$ & $\begin{array}{c}\text { Electron energy } \\
40 \mathrm{eV}\end{array}$ & $30 \mathrm{eV}$ & $20 \mathrm{eV}$ & \\
\hline 45 & 1000 & 1000 & 1000 & 1000 & 950 & $\mathrm{CH}_{3} \mathrm{CH}_{2} \mathrm{O}^{+}$ \\
\hline 59 & 305 & 330 & 273 & 351 & 364 & $\mathrm{CH}_{3} \mathrm{CH}_{2} \mathrm{OCH}_{2}^{+}$ \\
\hline 73 & 340 & 390 & 350 & 527 & 709 & $\mathrm{CH}_{3} \mathrm{CH}_{2} \mathrm{OCH}_{2} \mathrm{CH}_{2}^{+}$ \\
\hline 89 & 383 & 473 & 464 & 755 & 1000 & $\mathrm{CH}_{3} \mathrm{CH}_{2} \mathrm{OCH}_{2} \mathrm{CH}_{2} \mathrm{O}^{+}$ \\
\hline 103 & 112 & 130 & 118 & 221 & 294 & $\mathrm{CH}_{3} \mathrm{CH}_{2} \mathrm{OCH}_{2} \mathrm{CH}_{2} \mathrm{OCH}_{2}^{+}$ \\
\hline 117 & 117 & 147 & 150 & 284 & 446 & $\mathrm{CH}_{3} \mathrm{CH}_{2} \mathrm{OCH}_{2} \mathrm{CH}_{2} \mathrm{OCH}_{2} \mathrm{CH}_{2}^{+}$ \\
\hline 133 & 140 & 180 & 189 & 383 & 607 & $\mathrm{CH}_{3} \mathrm{CH}_{2} \mathrm{O}\left(\mathrm{CH}_{2} \mathrm{CH}_{2} \mathrm{O}\right)_{2}^{+}$ \\
\hline 147 & 24 & 28 & 27 & 60 & 84 & $\mathrm{CH}_{3} \mathrm{CH}_{2} \mathrm{O}\left(\mathrm{CH}_{2} \mathrm{CH}_{2} \mathrm{O}\right)_{2} \mathrm{CH}_{2}^{+}$ \\
\hline 161 & 17 & 21 & 23 & 50 & 79 & $\mathrm{CH}_{3} \mathrm{CH}_{2} \mathrm{O}\left(\mathrm{CH}_{2} \mathrm{CH}_{2} \mathrm{O}\right)_{2} \mathrm{CH}_{2} \mathrm{CH}_{2}^{+}$ \\
\hline 177 & 24 & 29 & 33 & 67 & 84 & $\mathrm{CH}_{3} \mathrm{CH}_{2} \mathrm{O}\left(\mathrm{CH}_{2} \mathrm{CH}_{2} \mathrm{O}\right)_{3}^{+}$ \\
\hline 191 & 2 & 2 & 4 & 4 & 6 & $\mathrm{CH}_{3} \mathrm{CH}_{2} \mathrm{O}\left(\mathrm{CH}_{2} \mathrm{CH}_{2} \mathrm{O}\right)_{3} \mathrm{CH}_{2}^{+}$ \\
\hline 205 & 1 & 2 & 2 & 4 & 5 & $\mathrm{CH}_{3} \mathrm{CH}_{2} \mathrm{O}\left(\mathrm{CH}_{2} \mathrm{CH}_{2} \mathrm{O}\right)_{3} \mathrm{CH}_{2} \mathrm{CH}_{2}^{+}$ \\
\hline 221 & 2 & 2 & 3 & 4 & 7 & $\mathrm{CH}_{3} \mathrm{CH}_{2}^{+} \mathrm{O}\left(\mathrm{CH}_{2} \mathrm{CH}_{2} \mathrm{O}\right)_{4}^{+}$ \\
\hline 235 & 1 & 1 & 1 & 1 & 1 & $\mathrm{CH}_{3} \mathrm{CH}_{2} \mathrm{O}\left(\mathrm{CH}_{2} \mathrm{CH}_{2} \mathrm{O}\right)_{4} \mathrm{CH}_{2}^{+}$ \\
\hline 249 & 1 & 1 & 1 & 1 & 2 & $\mathrm{CH}_{3} \mathrm{CH}_{2} \mathrm{O}\left(\mathrm{CH}_{2} \mathrm{CH}_{2} \mathrm{O}\right)_{4} \mathrm{CH}_{2} \mathrm{CH}_{2}^{+}$ \\
\hline 265 & 1 & 1 & 1 & 1 & 1 & $\mathrm{CH}_{3} \mathrm{CH}_{2} \mathrm{O}\left(\mathrm{CH}_{2} \mathrm{CH}_{2} \mathrm{O}\right)_{5}^{+}$ \\
\hline 279 & 1 & 1 & 1 & 1 & 1 & $\mathrm{CH}_{3} \mathrm{CH}_{2} \mathrm{O}\left(\mathrm{CH}_{2} \mathrm{CH}_{2} \mathrm{O}\right)_{5} \mathrm{CH}_{2}^{+}$ \\
\hline
\end{tabular}

increased at the low energy range. No other peak above 45 a.m.u. was detected at this temperature range. It has been known the PEO is susceptible to marked free radical oxidative attack during storage at ambient temperatures [2] and to formation of many oxygenated products. Thus peak at 45 a.m.u. observed at low temperature range may be attributed to an oxidative degradation product of PEO absorbed on the polymer. Furthermore it may be concluded that degradation of the polymer does not start below $220^{\circ}$. Sudden increase in the total ion current above $230^{\circ}$ indicated that thermal decomposition of the polymer had started. All the peaks observed showed a very similar trend in $225-255^{\circ}$ range.

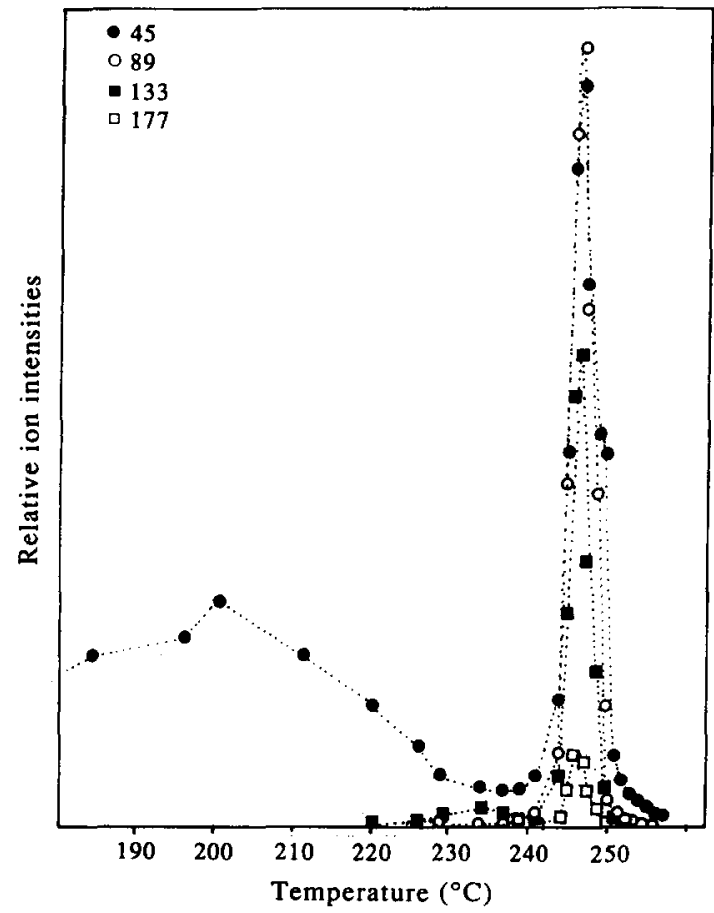

Fig. 4. Variation of intensities of peaks at 45, 89, 133 and 177 a.m.u. as a function of temperature at ionization energy of $20 \mathrm{eV}$.
These results indicate that decomposition of the polymer is possible at any point along the chain.

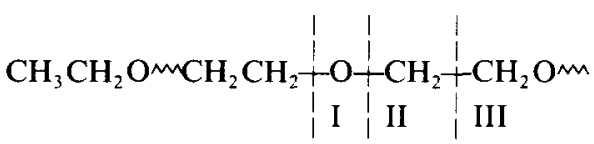

It has been postulated that degradation of pure $\mathrm{PEO}$ should initiate by random $\mathrm{C}-\mathrm{O}$ and $\mathrm{C}-\mathrm{C}$ scissions and that the radicals formed may depolymerize evolving volatile components such as ethylene, formaldehyde and acetaldehyde [1]. Thus the peaks observed in the spectrum at low ionization energies $(20 \mathrm{eV})$ are directly related to thermal decomposition products. It is also noted that, the relative intensities of the main ions decreased in the order of

$$
\begin{aligned}
& \mathrm{CH}_{3} \mathrm{CH}_{2} \mathrm{O}\left(\mathrm{CH}_{2} \mathrm{CH}_{2} \mathrm{O}\right)_{n}^{+} \\
& \quad>\mathrm{CH}_{3} \mathrm{CH}_{2} \mathrm{O}\left(\mathrm{CH}_{2} \mathrm{CH}_{2} \mathrm{O}\right)_{n-1} \mathrm{CH}_{2} \mathrm{CH}_{2}^{+} \\
& \quad>\mathrm{CH}_{3} \mathrm{CH}_{2} \mathrm{O}\left(\mathrm{CH}_{2} \mathrm{CH}_{2} \mathrm{O}\right)_{n-1} \mathrm{CH}_{2}^{+} .
\end{aligned}
$$

It has been shown that polymers containing oxygen in the main chain tend to degragate more readily than those containing only carbon atoms in their backbone $[6,14]$. This is expected on the bases of carbon-oxygen and carbon-carbon bond energies. Thus it can be concluded that cleavages of the polymer chain next to the oxygen atom at I and II positions are more significant during thermal degradation of PEO.

Experiments were repeated using $4 \times 10^{6} \mathrm{~g} \cdot \mathrm{mol}^{-1}$ PEO samples. The very identical results obtained indicated that the technique used, although not sensitive to molecular weight of the polymer under investigation, at least in this molecular weight range, gives reproducible results.

\section{Evolved gas analysis}

In evolved gas analysis, peaks due to pyrolysis products started to appear after the oven temperature reached $200^{\circ}$. Total ion yield continuously increased and reached its maximum value at $280^{\circ}$. The mass spectrum recorded at this temperature is given in Fig. 5. No ion above 100 a.m.u. was observed at any time during the experiment at any temperature. Thus it 


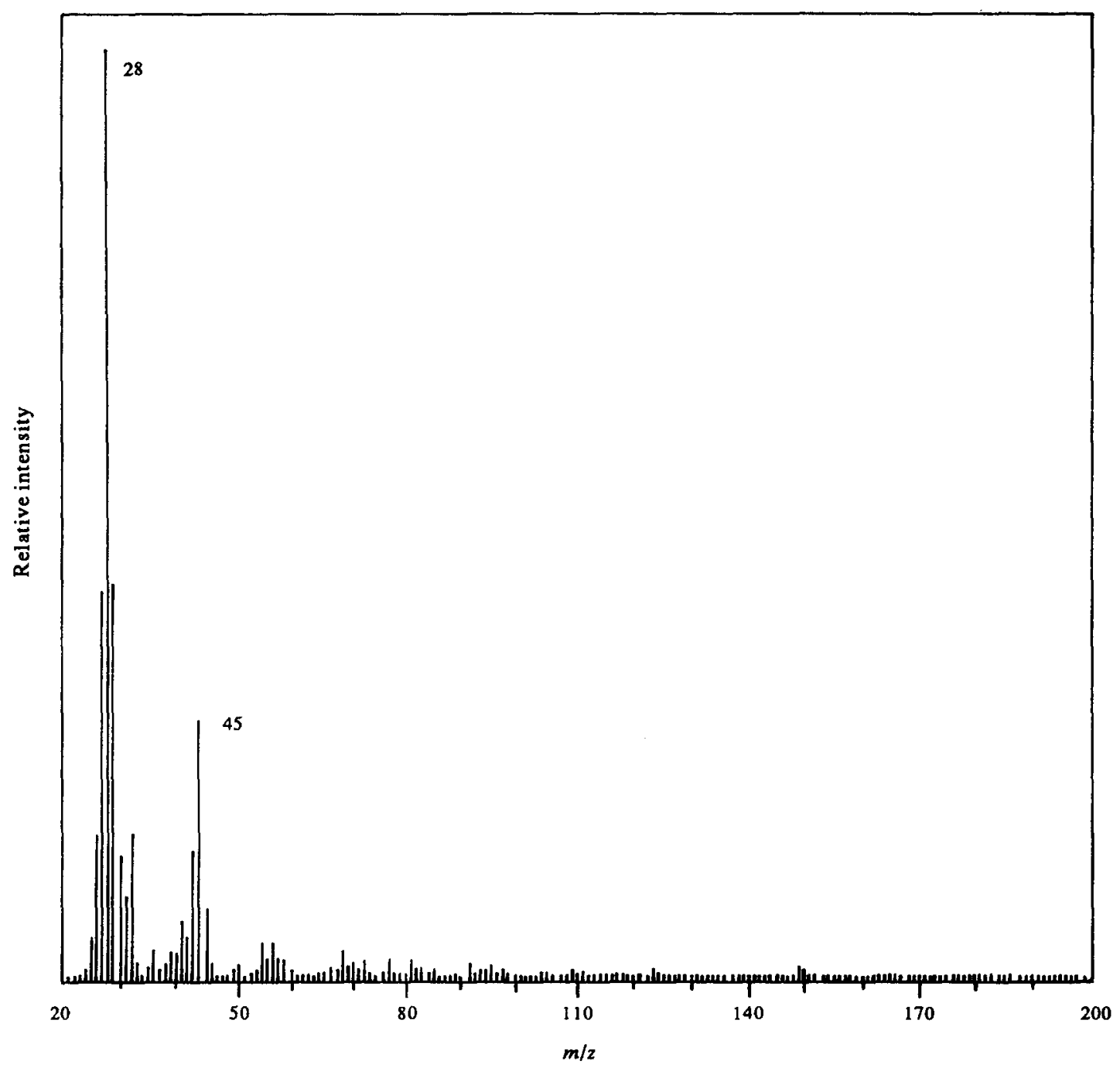

Fig. 5. Mass spectrum of indirect pyrolysis products of PEO at $280^{\circ}$.

can be concluded that only stable, volatile lowmolecular weight products could reach the ion source under the experimental conditions. The base peak was at 28 a.m.u. throughout the experiment. Strong peaks at $31,44,45,55,59,73,81$ and 96 a.m.u. were detected. Variation of intensities of the peaks as a function of temperature indicated that peaks at 96,81 and 55 a.m.u. and 73, 59, 45 and 31 a.m.u. were interrelated.

Peaks at 96,81 and 55 a.m.u. may be attributed to an unsaturated cyclohexanone that would give rise to these peaks by the following mechanism [15]:<smiles>C[C-]CC1CC=CCC1=O</smiles><smiles>[O+]#CC1CC=C[CH+]C1</smiles><smiles>C/C=C\CC(C#[O+])C=CC#[Fe+]</smiles>

(96 a.m.u.)

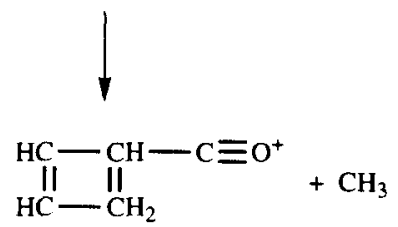

(81 a.m.u.) 
The presence of peaks at $31,45,59$ and 73 a.m.u. can be related to $\mathrm{CH}_{3} \mathrm{CH}_{2} \mathrm{OCH}_{2} \mathrm{CH}_{3}$ molecule which will yield $\mathrm{CH}_{3} \mathrm{CH}_{2} \mathrm{OCH}_{2} \mathrm{CH}_{2}^{+}, \mathrm{CH}_{3} \mathrm{CH}_{2} \mathrm{OCH}_{2}^{+}$, $\mathrm{CH}_{3} \mathrm{CH}_{2} \mathrm{O}^{+}$and $\mathrm{CH}_{2} \mathrm{O}^{+}$ions at the observed $\mathrm{m} / \mathrm{z}$ values. However the trends in ion yields of peaks at 59,45 and 31 as a function of temperature indicate that these peaks should be also due to another stable molecule, most probably $\mathrm{CH}_{3} \mathrm{CH}_{2} \mathrm{OCH}_{3}$.

Low mass peaks at 44,31 and 28 a.m.u. can be also directly assigned to $\mathrm{CH}_{3} \mathrm{CHO}$ and $\mathrm{CO}_{2}, \mathrm{CH}_{2} \mathrm{O}$, $\mathrm{CO}$ and $\mathrm{C}_{2} \mathrm{H}_{4}$ respectively with the use of literature data [1].

\section{CONCLUSION}

The direct pyrolysis technique used gives diagnostic data related to the polymer sample under investigation. Degradation of $\mathrm{PEO}$ occurred at the temperature range $235-255^{\circ}$ by both $\mathrm{C}-\mathrm{O}$ and $\mathrm{C}-\mathrm{C}$ scission, products due to $\mathrm{C}-\mathrm{O}$ cleavages being more abundant. Peaks related to degradation products upto six monomer units were detected. The main degradation products are $\mathrm{CH}_{3} \mathrm{CH}_{2} \mathrm{O}\left(\mathrm{CH}_{2} \mathrm{CH}_{2} \mathrm{O}\right)_{n}$ $\mathrm{CH}_{2} \mathrm{CH}_{2}^{+}, \quad \mathrm{CH}_{3} \mathrm{CH}_{2} \mathrm{O}\left(\mathrm{CH}_{2} \mathrm{CH}_{2} \mathrm{O}\right)_{n} \mathrm{CH}_{2}^{+}$and $\mathrm{CH}_{3} \mathrm{CH}_{2} \mathrm{O}\left(\mathrm{CH}_{2} \mathrm{CH}_{2} \mathrm{O}\right)_{n}^{+}$where $n=0-6$. However with the use of evolved gas analysis technique by mass spectrometry, an indirect pyrolysis method, only low molecular weight volatile products such as $\mathrm{CO}_{2}, \mathrm{CH}_{2} \mathrm{O}, \mathrm{CH}_{3} \mathrm{CHO}$ and $\left(\mathrm{CH}_{3} \mathrm{CH}_{2}\right)_{2} \mathrm{O}$ could be identified. A large variety of molecules might be produced in the reactor during pyrolysis. These thermally stable components may not even be directly related to the sample under study. Thus the spectra obtained are much complicated but less characteristic compared to those recorded in the case of direct pyrolysis. Therefore the direct pyrolysis MS technique should be preferential especially for structural analysis whereas indirect pyrolysis can be applied to investigate stable degradation products of a polymer sample.

Acknowledgment-We acknowledge financial support provided by METU through the research Grant No. AFP92-01-03-01.

\section{REFERENCES}

1. N. Grassie and A. Perdomo Medoza. Polym. Deg. Stab. 9, 155 (1984) and C. G. Cameron, M. D. Ingram, M. Y. Qureshi, H. M. Gearing, L. Costa and G. Camino. Eur. Polym. J. 25, 779 (1989).

2. S. W. Bigger, J. Scheirs, O. Delatycki and N. C. Billingham. Polym. Int. 26, 181 (1991) and references cited therein.

3. D. G. H. Ballard, P. Cheshire, T. S. Mann and J. E. Prezeworski. Macromolecules 23, 1256 (1990).

4. E. Clahorra, M. Cortazar and G. M. Guzman. J. Polym. Sci.; Polym. Lett. Edn 23, 257 (1985).

5. Y. Nishio, N. Hirose and T. Takahashi. Polym. J. 21, 347 (1987).

6. J. Scheirs, S. W. Bigger and O. Delatycki. Polymer 32, 2014 (1991).

7. A. M. Afifi-Effat and J. May. Eur. Polym. J. 8, 289 (1972).

8. I. C. McNeil. Eur. Polym. J. 3, 409 (1967); 6, 373 (1970); I. C. McNeil and M. A. J. Mohammed. Eur. Polym. J. 8, 975 (1972).

9. M. Erdogan, T. Yalcin, T. Tincer and S. Suzer. Eur. Polym. J. 27, 413 (1991).

10. B. Ozden, T. Yalcin and S. Suzer. J. Molec. Struc. 267, 135 (1992).

11. T. Yalcin, U. Akbulut and S. Suzer. Macromol. Reports A30, 55 (1993).

12. H. Schulten, N. Simmleit and R. Muller. Analyt. Chem. 1, 221 (1989).

13. H. Ohtani, T. Yuyama, S. Tsuge, P. Plage and H. R. Schulten. Eur. Polym. J. 26, 93 (1990).

14. H. Vink. Macromolec. Chem. 67, 105 (1963).

15. R. Dawis and F. Freason. Mass Spectrometry. John Willey \& Sons, London (1987). 